\title{
Polityka państwowa wobec sektora malych i średnich firm w latach 1990-2000
}

W okresie transformacji gospodarki narodowej szczególnego znaczenia nabieraja zmiany struktury własnościowej podmiotów gospodarczych. Konieczność tych zmian jest bowiem uważana za niezbędny warunek zwiększenia efektywności gospodarki oraz podwyższenia poziomu życia społeczeństwa. W polskich warunkach istotnym elementem przekształceń własnościowych jest rozwój sektora małych i średnich przedsiębiorstw (MSP). Przedsiębiorstwa tej kategorii aktywnie uczestniczą w procesach demonopolizacji i restrukturyzacji gospodarki, budowie infrastruktury ekonomicznej, koniecznej do efektywnego funkcjonowania całej gospodarki (Sobczyk 1999). Drobne firmy odznaczają się elastycznością działania, mobilnością, większą odpornością na zjawiska kryzysowe i dużą efektywnością działania. Stwarzają dodatkowe miejsca pracy, opierają się głównie na lokalnych surowcach oraz doskonale sprawdzają się w kooperacji z dużymi przedsiębiorstwami (Kamińska 1996).

W Polsce dynamiczny rozwój małych i średnich prywatnych zakładów rozpoczął się po wprowadzeniu w życie Ustawy o działalności gospodarczej z 23 grudnia 1988 r. (Dz. U. Nr 41 z późn. zmianami). Stworzyła ona przesłanki do rozwoju prywatnej przedsiębiorczości bowiem zrównała pod względem prawnym wszystkie formy własności, wprowadziła uproszczoną procedurę ewidencyjną oraz znacznie ograniczyła monopol państwa.

W latach 1993-99 udział sektora małych i średnich firm w liczbie pracujących w całej polskiej gospodarce wzrósł z $55,7 \%$ do $64,2 \%$. W okresie tym powiększył się także udział analizowanego sektora w przychodach ze sprzedaży produktów i usług w całej gospodarce narodowej z $40 \%$ do $63 \%$ oraz udział w nakładach inwestycyjnych w sektorze przedsiębiorstw z 38\% do 46,8\% (Raport ... 2001). Powyższe dane wskazują, że sektor małych i średnich przedsiębiorstw odgrywa w gospodarce polskiej coraz poważniejszą rolę. Stanowi istotne źródło wzrostu gospodarczego i czynnik ograniczenia bezrobocia.

Rządy państw wysokorozwiniętych doceniając rolę sektora MSP w gospodarce narodowej prowadzą politykę stymulowania i ochrony działalności sektora małych i średnich firm, doskonaląc stale instrumenty tej polityki i poszerzając zakres ich działania. Polityka wobec drobnych przedsiębiorstw ma na celu tworzenie szans stabilizacji, pobudzanie pożądanych $-\mathrm{z}$ punktu widzenia ogólnych interesów społeczno-gospodarczych tendencji rozwoju oraz kształtowanie warunków wykorzystania tkwiących w tym sektorze potencjalnych możliwości dla przyspieszenia rozwoju nowych technologii i wzmocnienia konkurencyjności własnej gospodarki na rynkach światowych (Mączyńska 1991). 
W świetle powyższych rozważań zachodzi pytanie jaką politykę wobec sektora MSP prowadzi rząd polski i jakie sa jej instrumenty?

Problematyka wspierania rozwoju małych i średnich przedsiębiorstw została szeroko omówiona zwłaszcza w literaturze ekonomicznej (Forst 1996, Grabowski, Kulawczuk 1991, Klich 2000, Miś, Ciosek 2000, Piasecki 1995, 1997, Vargas 1999). W rozważaniach tych przeważa pogląd, że rozwój sektora małych firm potrzebuje odpowiedniej polityki zawierającej spójny system preferencji dla małych podmiotów gospodarczych oraz wachlarz instrumentów (finansowych i organizacyjnych) do jego realizacji. W okresie transformacji gospodarki narodowej konieczne jest wypracowanie nowych jakościowo modeli wsparcia rozwoju przedsiębiorczości zapewniających kompleksowość przyjętych rozwiązań. Programy te powinny uwzględniać potrzebę (Piasecki $1995 \mathrm{~s} .15$ ):

- uznania rozwoju MSP za centralny problem struktury własności i kultury społeczeństw

- uświadomienia politykom oraz administracji centralnej, regionalnej i lokalnej ich roli w kreowaniu przedsiębiorczych postaw,

- zbudowania instytucjonalnego wsparcia rozwoju MSP, w tym pozarządowych form współpracy i kooperacji małego biznesu oraz rozwoju lokalnych, regionalnych i centralnych szczebli samorządu gospodarczego,

- przygotowania instrumentów wspierających rozwój lokalnych i regionalnych płaszczyzn współdziałania instytucji administracji rządowej, samorządu lokalnego i samorządu gospodarczego, instytucji pararządowych i instytucji nonprofitowych oraz osób (podmiotów) nie stowarzyszonych na rzecz promowania aktywnego wsparcia rozwoju małych i średnich przedsiębiorstw.

\section{Działania państwa na rzecz sektora MSP w Polsce}

W Polsce polityka wspierania małej przedsiębiorczości była prowadzona od początku okresu transformacji. W pierwszych latach sprowadzała się ona głównie do usuwania ograniczeń prawnych i wprowadzania przepisów ułatwiających podejmowanie działalności gospodarczej. Nie dopracowano się wówczas skoordynowanych rozwiązań $w$ zakresie promowania small businessu, ale liberalizacja przepisów prawnych spowodowała dynamiczny rozwój małych i średnich przedsiębiorstw (Kamińska 1996).

Już w 1990 r. uchwałą Rady Ministrów powołano Urząd Pełnomocnika ds. Popierania Przedsiębiorczości (Uchwała RM Nr 181/90 z 19 listopada 1990 r.). Do jego zadań należało m.in.:

1. Kreowanie w społeczeństwie etosu przedsiębiorczości.

2. Ułatwianie dostępu do informacji marketingowych, technicznych, ekonomicznofinansowych, prawnych itp. wszystkim zainteresowanym działalnością gospodarczą.

3. Stwarzanie możliwości szkolenia się i darmowego lub taniego doradztwa.

4. Ułatwianie nowym jednostkom startu i umacnianie ich sytuacji ekonomicznej w początkowym okresie działalności.

5. Tworzenie korzystnych warunków wzrostu małej skali produkcji, opartej na środkach własnych i kredytach.

6. Stymulowanie rozwoju sektora w kierunkach zgodnych z potrzebami regionu i kraju.

7. Wzmacnianie ochrony produkcji w małej skali przed działaniami monopolistycznymi. 
8. Skuteczne blokowanie wszelkiej inicjatywy prawno-systemowej utrudniającej rozwój drobnej wytwórczości.

W późniejszych okresach przyjmowano wiele programów mających na celu wspieranie rozwoju małych i średnich przedsiębiorstw. Podstawowymi dokumentami, w którym rząd określił politykę wobec sektora MSP były:

- Strategia dla Polski przyjęta w 1994 r.,

- Strategia dla Polski. Pierwszy rok realizacji i dalsze zamierzenia, przyjęta w 1995 r.,

- Strategia dla Polski. Pakiet 2000, przyjęta w 1996 r.

- Polska 2025. Długookresowa Strategia Trwałego i Zrównoważonego Rozwoju przyjęta w $2000 \mathrm{r}$.

Wśród działań w obszarze gospodarki wyodrębniono problematykę małych i średnich przedsiębiorstw, które uznano za sektor strategiczny ze względu na jego rolę w dynamizowaniu rozwoju, przyspieszaniu zmian strukturalnych oraz podkreślono konieczność wsparcia (Raport ... 2001).

W Długookresowej Strategii przedstawiono następujące zadania wobec małych i średnich przedsiębiorstw

- stworzenie odpowiedniego otoczenia prawnego i instytucjonalnego sprzyjającego powstawaniu i rozwojowi małych i średnich przedsiębiorstw,

- pobudzanie innowacyjności i ułatwianie dostępu do technologii w celu zwiększania konkurencyjności sektora,

- rozwój powiązań kooperacyjnych MSP z innymi przedsiębiorstwami (dużymi średnimi i małymi)

- zwiększanie aktywności eksportowej,

- zdynamizowanie rozwoju małych i średnich przedsiębiorstw w polityce strukturalnej państwa,

- promowanie ekologicznych metod zarządzania i produkcji.

Z punktu widzenia celów, które są realizowane przez państwo wobec sektora MSP politykę państwa można podzielić na 2 obszary (Raport... 2001, Vargas 1999):

- politykę wobec sektora MSP sensu stricte, której celem jest tworzenie warunków funkcjonowania i rozwoju małych i średnich przedsiębiorstw

- politykę wobec innych dziedzin realizujących priorytetowo cele społeczno-gospodarcze, w których małe i średnie przedsiębiorstwa występują jako jeden z instrumentów realizacji.

Politykę wobec sektora małych i średnich przedsiębiorstw rząd realizuje za pomocą następujących instrumentów (Tkaczyk 1999, Kierunki ....1999):

- prawnych,

- finansowych,

- organizacyjnych,

- informacyjno-szkoleniowych. 


\section{Polityka państwa w zakresie wspierania sektora MSP za pomocą instrumen- tów prawnych}

W zakresie instrumentów prawnych kolejne rządy zamierzały realizować politykę wobec sektora MSP poprzez następujące działania (Kierunki ... 1999):

- dokonanie przeglądu i nowelizacji prawa cywilnego, handlowego, o zamówieniach publicznych itp.

- przygotowanie aktów prawnych ułatwiających funkcjonowanie małych podmiotów gospodarczych (np. ustawy: „Prawo działalności gospodarczej”, „Ordynacja podatkowa”, „o Krajowym Rejestrze Sądowym”)

- stworzenie systemu prawnego określającego podstawy tworzenia i funkcjonowania instytucji finansowych obsługujących lokalne fundusze poręczeń,

- opracowanie ustawy o utworzeniu Agencji Promocji i Rozwoju Przedsiębiorczości,

- przeanalizowanie uregulowań prawnych $w$ zakresie ułatwień $w$ procedurach celnych, tranzytowych i granicznych w obrotach handlowych Polski z zagranicą i przystosowanie ich pod kątem potrzeb sektora MSP,

- uproszczenie zasad, warunków i procedur ubezpieczeń kredytów eksportowych.

Działania legislacyjne rządu wydają się szczególnie ważne. One bowiem w głównym stopniu ułatwiają bądź utrudniają powstawanie nowych i rozwój już istniejących podmiotów gospodarczych. Często zmieniające się przepisy prawne, ich wieloznaczność oraz brak przejrzystości są bowiem jedną z najczęściej wymienianych barier rozwoju przedsiębiorczości w Polsce. Jak podaje E Małecka (1999) tylko w okresie od grudnia 1994 r. do czerwca 1996 r. dokonano 128 nowelizacji w 76 aktach prawnych regulujących działalność gospodarczą.

W latach 1990-2000 w Polsce uchwalono kilkadziesiąt aktów prawnych regulujących rozwój MSP. Do najważniejszych należy zaliczyć:

- ustawę Ordynacja podatkowa

- ustawę Prawo bankowe

- ustawę o poręczeniach i gwarancjach udzielanych przez Skarb Państwa oraz niektóre osoby prawne

- ustawę o Krajowym Rejestrze Sądowym

- ustawę Prawo działalności gospodarczej

- ustawę o warunkach dopuszczalności i nadzorowaniu pomocy publicznej dla przedsiębiorców.

Dla rozwoju przedsiębiorczości w Polsce fundamentalne znaczenie miała ustawa

o działalności gospodarczej uchwalona jeszcze w 1988 r. (Dz. U. 1988, Nr 41), która gruntownie zmieniła podejście do działalności gospodarczej i warunków jej rozwoju. Ustawa z $1988 \mathrm{r}$. była najczęściej zmienianym aktem prawnym regulującym prowadzenie działalności gospodarczej w Polsce. W latach 1988-1999 dokonano w niej aż 42 zmiany. Zmiany te $w$ głównej mierze dotyczyły działalności koncesjonowanej i generalnie szły w kierunku wydłużania listy tego rodzaju działalności.

Inne istotne zmiany to:

- wprowadzenie obowiązku uzyskania wpisu do Krajowego Rejestru Sądowego,

- wprowadzenie obligatoryjności posiadania rachunku bankowego przez przedsiębiorcę i wskazania go właściwemu urzędowi skarbowemu i ZUS, 
- wprowadzenie przepisów o zakazie nieuczciwej konkurencji

- 19 listopada 1999 r. sejm przyjął nową ustawę regulującą podejmowanie działalności gospodarczej „Prawo działalności gospodarczej”. Jednocześnie straciła moc ustawa z 1988 r. Uchwalona ustawa weszła w życie niedawno, dlatego zbyt wcześnie jest by oceniać jej oddziaływanie na rozwój przedsiębiorczości. Jednak należy podkreślić, że nakłada ona na organy administracji publicznej obowiązek tworzenia korzystnych warunków dla funkcjonowania i rozwoju małych i średnich przedsiębiorstw. Ustawa bowiem w art. 53 stanowi, że ,państwo stwarza, z poszanowaniem zasad równości i konkurencji, korzystne warunki dla funkcjonowania i rozwoju małych i średnich przedsiębiorców poprzez:

- inicjowanie zmian stanu prawnego sprzyjających rozwojowi małych i średnich przedsiębiorców, w tym dostępu do środków finansowych pochodzących z kredytów i pożyczek oraz poręczeń kredytowych,

- wspieranie instytucji umożliwiających finansowanie działalności gospodarczej na dogodnych warunkach,

- wyrównywania warunków wykonywania działalności gospodarczej ze względu na obciążenia publicznoprawne,

- ułatwianie dostępu do informacji, szkoleń oraz doradztwa,

- wspieranie instytucji i organizacji lokalnych oraz regionalnych dzialających na rzecz małych i średnich przedsiębiorców,

- promowanie współpracy małych i średnich przedsiębiorców z innymi przedsiębiorcami polskimi i zagranicznymi ze szczególnym uwzględnieniem przedsiębiorczości lokalnej.

Wśród instrumentów prawnych istotnie wpływających na warunki prowadzenia działalności gospodarczej ma także nowelizacja Kodeksu cywilnego. Wprowadzono w nim regulację umowy leasingu oraz umowę agencji. Jest to bardzo ważny element, zwłaszcza, że leasing jest uważany za formę finansowego wspierania małych firm.

Obok wymienionych aktów prawnych ustanowiono szereg ważnych dla przedsiębiorców regulacji, które pośrednio przyczyniają się do rozwoju przedsiębiorczości. Do nich należy m.in. ustawa o zasadach wspierania rozwoju regionalnego, w której ustanowiono podwaliny regulacji regionalnej polityki państwa (Raport... 2001). Dzięki niej Polska będzie mogła ubiegać się o fundusze Unii Europejskiej. Wiele z nich można będzie przeznaczyć na infrastrukturę gospodarczą oraz pomoc dla małych i średnich przedsiębiorstw.

W ramach regulacji prawnych nie udało się wprowadzić zmian do Kodeksu pracy, przynajmniej w takim zakresie jaki sugerowali pracodawcy. Chodziło tu głównie zmniejszanie kosztów związanych $\mathrm{z}$ zatrudnieniem pracowników, zwiększenie liczby dopuszczalnych godzin nadliczbowych czy przywrócenie możliwości zawierania nieograniczonej ilości umów na czas określony.

\section{Polityka państwa w zakresie wspierania sektora MSP za pomocą instrumen- tów finansowych}

W zakresie instrumentów finansowych podjęte zostały następujące działania (Kierunki ... 2000):

- wprowadzenie systemu poręczeń kredytowych dla MSP 
- wprowadzenie systemu regwarancji kredytowych

- opracowanie i wdrożenie systemów kryteriów udzielania MSP pomocy publicznej,

- wspieranie MSP na terenach wiejskich,

- dofinansowanie usług dla MSP, świadczonych przez Agencję Techniki i Technologii i inne ośrodki, polegających na udzielaniu informacji o innowacjach i nowych technologiach,

- wspieranie udziału MSP w ekspozycjach (krajowych i międzynarodowych), w misjach handlowych organizowanych przez samorządy gospodarcze, w dostępie do publikacji, seminariów i szkoleń

- współfinansowanie kosztów udziału MSP w programach Unii Europejskiej

- wsparcie kapitałowe istniejących i nowo tworzonych lokalnych i regionalnych funduszy poręczeń kredytowych przez dofinansowanie ich ze środków publicznych i ze środków pomocowych,

- wzmocnienie instrumentów stosowanych przez Agencję Restrukturyzacji i Modernizacji Rolnictwa, umożliwiających udzielanie pożyczek na rozpoczęcie działalności gospodarczej na terenie gmin wiejskich oraz miejsko-wiejskich, a także miast do 20 tys. mieszkańców poprzez rozszerzenie zakresu podmiotów mogących ubiegać się o uzyskanie pożyczki.

Do instrumentów finansowych najczęściej stosowanych należy zaliczyć:

- poręczenia kredytowe

- kredyty i pożyczki

- ulgi i preferencje podatkowe

- inne (np. zamówienia publiczne, finansowanie udziału w targach i wystawach zagranicznych).

\section{Poręczenia kredytowe}

Ich podstawowym celem jest ułatwiania dostępu do kredytów bankowych poprzez udzielanie poręczeń spłaty kredytów. W Polsce w 1997 r. powstał Krajowy Fundusz Poręczeń Kredytowych (KFPK). Fundusz został zasilony kwotą $45 \mathrm{mln}$ zł. z budżetu państwa. Do końca 1999 r. z Funduszu zostało udzielonych 507 poręczeń na kwotę 156,5 mln zł (Finansowanie ... 2000). Ponadto w Polsce działa 15 lokalnych funduszy poręczeniowych Do końca 1997 r. fundusze te udzieliły 707 poręczeń na kwotę $25,5 \mathrm{mln}$ zł. Liczby te wyraźnie wskazują iż pomoc tego rodzaju jest bardzo ograniczona. Dodatkową przeszkodą jest brak informacji o działalności KFPF.

\section{Kredyty i pożyczki}

Jedną z poważniejszych barier w rozwoju MSP jest brak kapitału. Badania wykazały, że przedsiębiorcy najczęściej korzystają z własnych, ograniczonych zasobów finansowych lub pomocy najbliższej rodziny i przyjaciól. Kredyty bankowe są drogie i trudno dostępne dla tej kategorii przedsiębiorstw. Dlatego też istotne znaczenie w rozwoju przedsiębiorczości ma opracowanie systemu tanich i dostępnych kredytów bankowych dla małych i średnich firm. 
Jedną z instytucji zajmującą się udzielaniem kredytów na prowadzenie działalności gospodarczej jest Agencja Techniki i Technologii (ATiT) finansowana z budżetu państwa. W latach 1997-99 do tej Agencji wpłynęło 213 wniosków o pożyczki, z czego ATiT zrealizowała zaledwie $43 \mathrm{tj}$. 20,2\%. W okresie tym wnioskowano o pomoc finansową w wysokości 111,5 mln zł, a ATiT udzieliła jej na kwotę 19,5 mln zł tj. 17,4\% (Raport... 2001).

Rząd wprowadził również pożyczki dla bezrobotnych podejmujących działalność gospodarczą oraz pracodawców tworzących nowe miejsca pracy. W ciągu 3 kwartałów 2000 r. na pożyczki wydatkowano $82,5 \mathrm{mln}$ zł. (Raport.... 2001).

Przy udzielaniu kredytów i pożyczek warto wspomnieć o pomocy zagranicznej. Małe i średnie przedsiębiorstwa są wspierane $\mathrm{z}$ funduszy oferowanych przez rządy poszczególnych państw zachodnich. Chodzi tu głównie o pomoc regulowaną przez umowy rządowe np. programy PHARE.

\section{Ulgi i preferencje podatkowe}

Wysokośč obciążeń podatkowych, jasność i przejrzystość przepisów mogą oddziaływać stymulująco lub hamująco na rozwój przedsiębiorczości. Badania przeprowadzone w 2000 r. wykazały, że prawie $40 \%$ przedsiębiorców uznaje obciążenia podatkowe za istotny hamulec w rozwoju firmy (Raport... 20001). W polskim systemie podatkowym istnieja ulgi i preferencje dla przedsiębiorców. Jedną z nich jest ulga inwestycyjna. Ulgi inwestycyjne początkowo były regulowane w drodze rozporządzeń. Podatnik mógł odliczyć określone wydatki inwestycyjne (np. na zakup maszyn i urządzeń). W 1997 r. przeniesiono te uregulowania do ustaw o podatku dochodowym od osób fizycznych. Wprowadzono także ulgi dla firm działających w gminach uznanych za zagrożone szczególnie wysokim bezrobociem strukturalnym lub zagrożonych strukturalną recesją $i$ degradacją społeczną. Natomiast od 1 stycznia 2001 r. zniesiono ulgi inwestycyjne zastępując je korzystniejszą amortyzacją.

Do preferencji zaliczyć można formy opodatkowania. Małe przedsiębiorstwa w Polsce mogą korzystać z tzw. uproszczonych form opodatkowania (karta podatkowa, ryczałt od przychodów ewidencjonowanych). Ich zaletą jest niższy poziom obciążeń, niższa pracochłonność czy prosta konstrukcja.

$\mathrm{Na}$ terenach gmin uznanych za zagrożone szczególnie wysokim bezrobociem strukturalnym dla osób fizycznych i prawnych prowadzących lub podejmujących działalność gospodarczą wprowadzono dodatkowe preferencje podatkowe. Istnieje m.in. możliwość odliczenia od dochodu do opodatkowania lub obniżenia podatku o 50\% (w gminach do 5000 mieszkańców o 75\%) kwoty wydatków inwestycyjnych i możliwość korzystania z podwyższonych stawek amortyzacyjnych umożliwiających szybszą amortyzację niektórych środków.

$\mathrm{Z}$ ulg podatkowych na określonych warunkach mogą również korzystać firmy działające w tzw. specjalnych strefach ekonomicznych.

Ostatnie dwunastolecie to okres powstawania w Polsce systemu podatkowego dostosowanych do nowych warunków gospodarowania. Wprowadzono w tym okresie liczne zmiany, które w sposób jednoznaczny przyczyniły się do skomplikowania przepisów. Widoczna jest tendencja do ciągłego deprecyzowania rozwiązań i sformułowań. Ciągłe zmiany stanu prawnego powodują konieczność nieustannego śledzenia różnych aktów prawnych. 


\section{Inne instrumenty finansowe}

Wśród tej grupy instrumentów warto wspomnieć o finansowaniu udziału MSP w zagranicznych targach i wystawach. Rada Ministrów sporządziła listę imprez targowych objętych w latach 2000-2002 systemem dofinansowania. Maksymalna kwota refundacji waha się od 5000 do 15000 PLN (w zależności od rangi wystawy).

W Polsce zamówienia publiczne nie są często stosowaną formą finansowego wspierania małych i średnich przedsiębiorstw. Należy jednak podkreślić że w nowej ustawie o zamówieniach publicznych obniżono wysokość wadium dla tej kategorii firm.

\section{Polityka państwa w zakresie wspierania sektora MSP za pomocą instrumen- tów organizacyjnych}

Działania rządowe w tym zakresie obejmowały (Kierunki... 2000):

- zainicjowanie pomocy mającej na celu powstawanie lokalnych sieci funduszy wspierających poręczenia MSP oraz opracowanie modelu lokalnego systemu poręczeń na podstawie środków pomocowych,

- wspieranie tworzenia systemu regionalnych towarzystw ubezpieczeń wzajemnych $\mathrm{i}$ innych pozabankowych instytucji finansowych,

- rozwijanie struktur organizacyjnych systemu kooperacji przemysłowej,

- utworzenie Fundacji Promocji i Rozwoju MSP,

- opracowanie raportu o dostępności, stopniu zaangażowania i efektywności wykorzystania środków pomocy zagranicznej, przeznaczonych na wsparcie MSP,

- utworzenie Agencji Promocji i Rozwoju Przedsiębiorczości (na bazie Polskiej Fundacji Promocji i Rozwoju MSP,

- utworzenie w Urzędzie Zamówień Publicznych centralnej bazy danych o zamówieniach publicznych orz zwiększenie dostępu MSP do ogólnej informacji o zamówieniach publicznych poprzez Krajowy System Usług i Internet

- opracowanie strategii promocji eksportu MSP,

- rozbudowa bazy danych o regulacjach prawnych w Unii Europejskiej

- stworzenie systemu wzajemnych gwarancji lokalnych i regionalnych funduszy poręczeń kredytowych

W zakresie działań organizacyjnych władz centralnych duże znaczenie miało utworzenie Polskiej Fundacji Promocji i Rozwoju Małych i Średnich Przedsiębiorstw. Fundacja ta prowadziła swoją działalność w latach 1995-2000. Od 1997 r. prace Fundacji nadzorowane były przez Ministerstwo Gospodarki. Celem działalności Fundacji było tworzenie warunków dla rozwoju sektora małych i średnich przedsiębiorstw. W ciągu 5 lat istnienia Fundacji stworzono infrastrukturę organizacyjną służącą wspieraniu sektora MSP w Polsce. Powstała sieć ośrodków Krajowego Systemu Usług, zorganizowano Centra Informacji Gospodarczej, powołano Polską Sieć Doradców Biznesu. Fundacja zajmowała się także wdrażaniem programów Unii Europejskiej przeznaczonych dla sektora MSP. W 2000 r. Fundację przekształcono w Polską Agencję Rozwoju Przedsiębiorczości. Celem Agencji jest udział w realizacji programów rozwoju gospodarczego, w szczególności w zakresie wspierania i rozwoju MSP (Raport ... 2001). 
Ważną instytucją działającą na rzecz wspierania przedsiębiorczości jest Agencja Techniki i Technologii (ATiT). Instytucja rozpoczęła działalność od utworzenia bazy informacyjnej o nowych organizacyjno-technicznych projektach możliwych do szybkiego wdrożenia, a następnie przystąpiła do ułatwiania kontaktów producentów z inwestorami kapitałowymi. W 1997 r. ATiT udzieliła wsparcia organizacyjno-finansowego 13 innowacyjnym projektom wdrożeniowym na kwotę 5,5 mln zł (Miś, Ciosek 2000). W 1999 r. ATiT zajęła się głównie tworzeniem, wspieraniem i współpracą z regionalnymi ośrodkami. Jak już wspomniano w latach 1997-99 do ATiT zgłoszono 213 wniosków o pożyczki na kwotę 111,5 mln zł. ATiT zrealizowała 43 wnioski $(20,2 \%)$ na kwotę $19,5 \mathrm{mln}$ zł. $(17,4 \%)$. (Raport... 2001).

\section{Polityka państwa w zakresie wspierania sektora MSP za pomocą instrumen- tów informacyjno-szkoleniowych}

Działania rządu w tym zakresie zmierzały głównie do (Kierunki... 2000):

- wspierania rozwoju regionalnych i lokalnych instytucji promujących i wspierających MSP,

- stworzenia systemu organizacji i procedury wspierania MSP w dostępie do technologii i wzornictwa przemysłowego,

- wspomagania działań zmierzających do poprawy konkurencyjności gospodarki,

- wspomagania zinstytucjonalizowanej pomocy w udostępnianiu wiedzy z zakresu finansów, zarządzania, marketingu, jakości i kształcenia zawodowego itp.,

- opracowania i włączania do programów nauczania przedmiotów propagujących przedsiębiorczość,

- opracowania i wdrożenia systemu monitorowania stanu MSP oraz ich wrażliwości na zmiany instrumentarium ekonomiczno-finansowego,

- rozpowszechniania informacji o możliwościach wykorzystania środków Funduszu Pracy przez przedsiębiorców tworzących nowe miejsca pracy,

- udostępniania przedsiębiorcom informacji o procedurach administracyjnych i celnych oraz o ułatwieniach w dostępie do rynków zagranicznych,

- udzielania pomocy doradczej i finansowej przy tworzeniu Funduszy Wzajemnych Ubezpieczeń Kontraktów Eksportowych

- przygotowania i wydawania materiałów dotyczących wdrażania norm ISO serii 9000, 14001 w MSP

- promowania poprzez rankingi banków udzielających kredytów przedsiębiorcom na najbardziej korzystnych zasadach

- organizowania seminariów i szkoleń dla pracowników banków i instytucji pozabankowych w celu upowszechnienia stosowania uproszczonych procedur przy udzielaniu pożyczek i kredytów dla MSP

Podstawowym celem przyjętym w zakresie instrumentów informacyjno-szkoleniowych było wspieranie rozwoju regionalnego i lokalnych instytucji promujących i wspierających MSP. Powołano 30 ośrodków afiliowanych przy regionalnych organizacjach przedsiębiorców, Agencjach i Fundacjach Rozwoju Regionalnego. Utworzono 20 regionalnych ośrodków 
informacji, 61 ośrodków wspierania przedsiębiorczości, 34 Fundacje Rozwoju Przedsiębiorczości i 31 inkubatorów przedsiębiorczości (Raport... 2001).

Rozpoczęto realizację ogólnopolskiej kampanii edukacyjno-informacyjnej. W czerwcu 2000 r. odbyła się Krajowa Konferencja MSP, pod patronatem Ministerstwa Gospodarki. Konferencji towarzyszyły Ogólnopolskie Targi „MSP-2000 - wszystko dla małych i średnich przedsiębiorstw"

Ministerstwo Edukacji Narodowej wprowadziło do podstaw programowych gimnazjów i szkól ponadpodstawowych informacje o podstawach gospodarki rynkowej.

Polska Fundacja Promocji i Rozwoju Małych i Średnich Przedsiębiorstw utworzyła 87 punktów konsultacyjno-doradczych świadczących bezpłatne usługi doradcze dla MSP. Z usług tych tylko w 2000 r. skorzystało 19800 klientów (Raport... 2001).

W budżecie państwa na 2000 r. przewidziano 20045 tys. zł na wykonanie zadań rządu wobec sektora MSP.

Aktywna polityka wspierania rozwoju MSP powinna zmierzać do stworzenia korzystnych warunków politycznych i prawno-ekonomicznych stymulujących prawidłowy rozwój tej grupy przedsiębiorstw. W Polsce od początku okresu transformacji tj. od $1989 \mathrm{r}$. władze centralne prowadzą działania w celu stworzenia kompleksowych możliwości rozwojowych. Wraz ze zmianami w gospodarce narodowej zmieniały się również cele polityki wspierania sektora MSP. Początkowo było to usuwanie barier prawnych, które umoźliwiły ilościowy wzrost tego sektora. Obecnie działania państwa skierowane są na zwiększenie konkurencyjności sektora MSP, wzrost eksportu oraz wzrost nakładów inwestycyjnych.

Rządowa polityka wspierania sektora MSP z pewnością wpłynęła na ilościowy wzrost tego sektora. Jednak jak wykazuje B. Piasecki (1995):

1. instytucje odpowiedzialne za działalność MSP i promocję przedsiębiorczości są zbyt słabe aby mogły wywierać presję na formułowanie polityki wobec tej grupy przedsiębiorców i dla obrony interesów tego sektora (m.in. ze względu na częste reorganizacje i zmiany personalne),

2. promocją przedsiębiorczości zajmuje się kilka ministerstw, instytucji i agencji rządowych co przyczynia się do powstawania problemów związanych z koordynacją działań na tym polu,

3. brak jest wiarygodnych informacji i analiz naukowych. koniecznych do sformułowania właściwej polityki

4. brak jest kanałów komunikacji pomiędzy przedsiębiorcami a politykami.

Przy wspieraniu przedsiębiorczości decydującą rolę winny pełnić władze na szczeblach regionalnych i lokalnych. Państwo winno stworzyć dogodne warunki prawne i makroekonomiczne dla rozwoju sektora MSP. Wynika to $\mathrm{z}$ faktu, że władze centralne nie posiadają wiedzy o specyfice potrzeb i regionalnych czy lokalnych problemach małych i średnich przedsiębiorstw.

\section{Literatura}

Berger K., 1999, Spatial pattern of small and medium enterprises in Poland. 1994-1996. [w:] Research Bulletin, vol. 8, nr 1, s. 51-60. 
Czternasty W., 1994 Wspomaganie rozwoju matych przedsiębiorstw $w$ Polsce $w$ okresie transformacji systemowej, [w:] Gospodarcze problemy transformacji ustrojowej, Zeszyty Naukowe AE Poznań, nr 222. s. 82-89.

Financing newly emerging private enterprises, in transition economies (Centre for $\mathrm{Co}-$ operation with Non - Numbers), 1999, OECD.

Forst M., 1996, Wsparcie dla malego biznesu w Europie Środkowej $i$ Wschodniej. [w:] Gospodarka Narodowa, nr 7, s. 69-74.

Grabowski M.H., Kulawczuk P., 1991, Finansowe wspieranie rozwoju małych i średnich przedsiębiorstw: rozwiqzania światowe i ich adaptacja do warunków polskich. Gdansk, Gdańska Grupa Promocyjna.

Gruchman B., Zawisny K., 1992, Metody $i$ instrumenty pobudzania przedsiębiorczości lokalnej, [w:] Gospodarka lokalna w warunkach samorządności, Zeszyty Naukowe AE, nr 205, s. 70-84.

Kamińska W., 1996, Pozarolnicza indywidualna dzialalność gospodarcza jako nowy element w strukturze gospodarczej Polski Poludniowo-Wschodniej, Biuletyn KPZK PAN nr 174, Warszawa.

Kierunki działań rządu wobec małych i średnich przedsiębiorstw do 2002 roku, 1999, Warszawa.

Klich J., (red.), 2000. Nadzieja rynku pracy: male i średnie przedsiębiorstwa $w$ gospodarce Wyd. ISP, Warszawa.

Mączyńska E., 1991, Jak to robiq inni. Male i średnie przedsiębiorstwa w RFN, „Rzeczpospolita” nr 106, dod. „Ekonomia i Prawo”.

Małecka E, 1999, Znaczenie matych firm w okresie transformacji. [w:] Gospodarka w Praktyce i Teorii, nr 1. s. 63-67.

Miś W., Ciosek A., 2000, Male i średnie przedsiębiorstwa (MSP) w polskich procesach rozwojowych, Zeszyty Naukowe Wyższej Szkoły Zarządzania i Marketingu w Warszawie, $\mathrm{nr}$ 2(8), s. 100-115.

Piasecki B., 1995, Dylematy polityki wspierania rozwoju sektora MSP w okresie transformacji. [w:] Uwarunkowania rozwoju sektora MSP w krajach Centralnej i Wschodniej Europy, red. B. Piasecki i Z. Konieczny, Wyd. UŁ, Łódź.

Piasecki B., 1997, Przedsiębiorczość i mata firma: teoria i praktyka, Lódź, Wyd. Uniwersytet Lódzki.

Raport o stanie sektora małych i średnich przedsiębiorstw w Polsce w latach 1999-2000. 2001 Warszawa.

Small business in Europe (red. Burns P.), 1986, Basinqstoke.

Sobczyk G., 1999, Mate firmy na rynku pracy w Polsce [w:] Polityka społeczna, nr 1, s. 16-19.

Tkaczyk T.P., 1999, Rynek, konkurencja i jej wspieranie. Monografie i Opracowania SGH nr 445, Warszawa.

Vargas M., 1999. Wspieranie malych i średnich przedsiębiorstw w Ameryce Łacińskiej i w Polsce. [w:] Ekonomika i Organizacja Przedsiębiorstwa, nr 6, s. 17-19. 